\title{
New Rights or New Business Models? An Inquiry into the Future of Publishing in the Digital Era
}

\author{
Martin Senftleben • Maximilian Kerk • \\ Miriam Buiten • Klaus Heine
}

Published online: 5 July 2017

(C) The Author(s) 2017. This article is an open access publication

\begin{abstract}
In its Proposal for a Directive on Copyright in the Digital Single Market, the European Commission included a new neighbouring right for press publishers with regard to the digital use of their publications "to ensure quality journalism and citizens' access to information." (European Commission, 14 September 2016, Proposal for a Directive of the European Parliament and of the Council on Copyright in the Digital Single Market, Doc. COM(2016) 593 final, Art. 11(1) and Recital 31.) Undoubtedly, a free and pluralist press is one of the cornerstones of democratic societies. The question is, however, whether this goal can be achieved by adopting an additional layer of protection. From an economic perspective, it seems essential that publishers, including press publishers, develop new business models in the digital environment. To ensure the survival of quality journalism, it is of utmost importance to support the transition to new business models that has already started in the publishing sector. Hence, the question arises whether the proposal of a new neighbouring right is a legislative initiative that makes sense against this background. To answer this question, the following inquiry will first provide an economic analysis of new business models in the publishing industry. On
\end{abstract}

M. Senftleben $(\bowtie)$

Professor of Intellectual Property and Director, Kooijmans Institute for Law and Governance, Vrije Universiteit Amsterdam; of Counsel, Bird \& Bird (The Hague), Amsterdam, The Netherlands e-mail: m.r.f.senftleben@vu.nl

M. Kerk

$\mathrm{PhD}$, Researcher, Rotterdam Institute of Law and Economics, Erasmus University Rotterdam, Rotterdam, The Netherlands

M. Buiten

Junior professor of Law and Economics, University of Mannheim, Mannheim, Germany

K. Heine

Professor of Law and Economics and Jean Monnet Chair of Economic Analysis of European Law, Erasmus University Rotterdam, Rotterdam, The Netherlands 
this basis, it becomes possible to assess the proposal of a new neighbouring right in the light of the need to develop new business models that are sustainable in the digital environment. The analysis will show that the introduction of a new neighbouring right is unlikely to offer support in this respect. Instead, it may even impede or delay necessary modernization steps.

Keywords EU copyright law $\cdot$ Neighbouring right of publishers $\cdot$ New business models $\cdot$ Content platforms $\cdot$ Community building $\cdot$ Branding and superstar culture

\section{Introduction}

In the digital environment, continuously more functions of supplying data and information are carried out by search engines, content aggregators and social media. ${ }^{1}$ These providers of online information services are not necessarily incumbent publishers. Instead, they have acquired a particularly strong market position by exploiting and leveraging their competitive advantage stemming from in-depth technological knowledge. This forces publishers to adopt new business models and use their specific competitive advantage which lies in particular expertise in the field of transforming raw data and individual information products into complex, interconnected information resources that facilitate and broaden access to the wide variety of sources of knowledge in the digital environment. Publishers are part of the group of service providers that organize the transformation of news, facts, and other sources of knowledge into complex information products with added value for readers. The bundling and enrichment of data and information has been their function for centuries. With the emergence of the Internet, societal demand for value-added information products has not decreased. Exactly the opposite is true because the Internet makes more and more data available to us. Hence, the Internet does not make publishers obsolete. However, it challenges existing business models and changes the landscape of the publishing industry.

With regard to the efforts made to develop new business models in the publishing sector, the question arises whether copyright in individual literary and artistic works - and the proposal of a neighbouring right relating to individual press publications ${ }^{2}$ - can still be deemed an appropriate instrument to stimulate and reward investment. Insofar as new business models are not primarily based on the commercialization of individual content but on the exploitation of a publisher's particular reputation or concept for an information database with added value, other protection regimes in the field of intellectual property enter the picture, in particular trade mark protection and sui generis database rights. Against this background, the question arises whether new forms of protection, such as the new neighbouring right proposed by the European Commission, ${ }^{3}$ would offer an appropriate incentive for publishers to

\footnotetext{
1 Cf. Peukert (2016), paras. 34-37; Xalabarder (2016), p. 4.

2 European Commission, 14 September 2016, Proposal for a Directive of the European Parliament and of the Council on Copyright in the Digital Single Market, Doc. COM(2016) 593 final, Art. 11(1).

${ }^{3}$ European Commission, ibid., Art. 11(1).
} 
develop new business models and pave the way for the continuance of quality journalism in the digital era. ${ }^{4}$ Before addressing this normative question, it is necessary to obtain a better understanding of the disruptive forces impacting the publishing market and requiring the development of new business models.

\section{Disruptive Forces}

For the purposes of the present analysis, a disruptive innovation can be regarded as an innovation that creates products that "are typically cheaper, simpler, smaller, and frequently, more convenient to use." 5 Such innovative products create new markets which ultimately disrupt existing markets and thereby challenge the position of incumbent market leaders. ${ }^{6}$ The term "disruptive innovation" was coined by Clayton M. Christensen who studied the phenomenon as of the mid-1990s. ${ }^{7}$

A technology is only said to be disruptive if it captures a very large share of the market. ${ }^{8}$ In practice, this means that very often a new technology is not disruptive at first, but only becomes disruptive once a way is found to make the technology available at low costs and on a large scale. As to the disruptive effect of digital technology on the publishing sector, it is advisable to have a closer look at the principal conditions and the situational context of the publishing business as it has been in the past and is going to change in the wake of digitization. In this way, the disruptive effect of digital technology clearly comes to the fore.

\subsection{Scale Economies and Network Effects}

As with other industries, the publishing industry strives for the creation of value that generates income. Broadly speaking, the creation of value means that a customer recognizes a product or service, be it as an intermediate good or for consumption. One may think of a scientific article that provides valuable information for improving a machine, teaching material used at school, or novels that provide a thrilling reading experience. A publisher seeking to create value will thus need the entrepreneurial capacity to identify and develop products or services that have value for the customer. As a result, value emerges with the customer who, in turn, will recognize the respective product or service.

However, value creation can also be understood in a more narrow sense. From the perspective of the publisher, it may simply mean the creation of profit - more precisely a profit that is comparable with the profit of other businesses and allows the publisher to attract shareholders and creditors as investors. For a publisher to make a profit in this sense, he must be able to gain power over market conditions to

\footnotetext{
${ }^{4}$ As to this overarching goal of the proposal to introduce a new neighbouring right, see European Commission, ibid., Recital 31.

5 Christensen (1997, p. xv).

6 Danneels (2006); Walsh et al. (2002).

7 Christensen and Bower (1995); Yu and Hang (2010).

${ }^{8}$ Govindarajan and Kopalle (2006); Slater and Mohr (2006).
} 
a certain extent. This goal can be achieved by developing a unique product or service that creates extra value for the customer, allowing the publisher to sell the good or service above his calculated costs. ${ }^{9}$ Alternatively, profit may result from the strategic use of knowledge about the technological preconditions of the publishing business. If a publisher knows how to economize on publishing costs, he can generate profit by decreasing production costs.

While it is certain that successful publishers are both, entrepreneurs who bring forth valuable products for customers and managers who bring down costs, it is worth reflecting on the latter aspect of cost reduction against the background of technological disruptions that follow from digitization and affect the cost management. Bringing costs down has by and large to do with the notion of "sub-additive cost functions". Sub-additivity means that cost advantages result from a larger market share, larger output, bigger synergies through diverse marketing activities or a complementary product portfolio. ${ }^{10}$ In this regard, a major shift has taken place as a result of the emergence of digital technology. While the supply side occupied centre stage in the analogue world, the digital environment has brought the demand side into focus. ${ }^{11}$

\subsection{Pre-Digital Era: Focus on the Supply Side}

In the pre-digital era of publishing, the making of profits via cost reductions was determined mainly by so-called "economies of scale": the larger the output of a print item, the cheaper the costs are per unit. Therefore, the better a publisher could calculate the mass sale of a print item, the cheaper the production would be at the printing press and the higher the profit would be. Hence, it was decisive that the publisher had sufficient expertise to determine with which authors and/or products it was profitable to have a large print run. Moreover, the relation between the publisher and the printer predetermined the chance of economizing on costs and making a profit. The sharing of risks and profits in the agreement concluded between the publisher and the printer occupied centre stage. Against this background, it did not come as a surprise that newspapers often had their own large printing machines which allowed them to economize on the costs over the full value chain of newspaper production. Because of this ownership structure and the economies of scale involved in the production process, the threat of new entrants was relatively low.

With regard to print products, such as newspapers, works of fiction, educational material, scientific journals, etc., one may identify diverse business models when embarking on a detailed study of the variations and nuances of individual production arrangements. Nonetheless, the overarching strategic issue was always one and the same recurring theme: the publisher relied on his expertise to determine which products (authors) could be sold in the market, and he would take a decision on the sellable quantity (the printing run) on the basis of his expertise. The decision

\footnotetext{
9 Wernerfelt (1984); Barney (1986).

${ }^{10}$ For an overview see Joskow (2007).

11 For a description of relevant supply and demand factors, see also Van Eechoud (2017), pp. 13-16.
} 
about the quantity was not only risky but also decisive for the possible profit margin that could be realized through economies of scale at the printing press. As a result, quite a lot of strategic concerns had to be given to the selection process of authors/ products and the subsequent contractual relation with the printer in the pre-digital era. To overcome contractual problems with printers, publishers - as pointed out, especially newspapers - were not unlikely to become owners of printers.

At a more abstract analytical level, one could say that in the pre-digital era, the business models of the publishing sector were (necessarily) supply-side driven. The focus on the supply side was a precondition for creating value for customers and generating sustainable profit margins.

\subsection{Digital Era: Focus on the Demand Side}

In the wake of digitization, the necessity of a strong focus on the selection of authors and the reduction of printing costs becomes less crucial. ${ }^{12}$ The sub-additivity of costs in the publishing business no longer rests predominantly with the printer of hardcopies. This shift is mainly due to two developments.

On the one hand, new print technologies, in particular printing on demand, became available which allow printing at reasonable costs for low quantities. During the last decade, printing on demand - meaning that a book is not printed until the publisher receives an order for the book from a customer - emerged as a new printing process. Printing on demand has become possible as a result of the development of digital printing technology which has markedly reduced the unit costs of printing. Whereas offset printing involves large economies of scale, digital printing allows for books to be printed at low cost in small quantities. This has made the sub-additivity of costs less crucial: rather than deciding whether or not to publish a book at all, the relevant consideration has become whether to publish a book using offset printing or digital printing, depending on the number of copies that are expected to be sold. Given the economies of scale involved in offset printing, offset printing is still more cost-effective for large quantities. The difference is that books that may not have been published in the pre-digital past because the printing costs could not be recovered, can now be profitable if printed on demand.

Besides reducing the minimum quantity for which printing a book is still profitable, printing on demand also ensures low storage costs for bookstores and prevents waste from unsold stock. Reducing the costs and risks of publishing a book and eliminating speculative stock, printing on demand, thus, has fundamentally changed the traditional publishing model which consisted of book printing as a first step and sales efforts concerning the books in stock as a second step. ${ }^{13}$

On the other hand, digital technology has led to an environment where content may be distributed without any printer when copies are only distributed in digital form. Hence, the traditional focus on the supply side has not only become less important because of new printing technology that allows the profitable commercialization of

\footnotetext{
12 Peukert (2016), para. 26.

13 Gallagher (2014).
} 
books for small audiences, it has also become less important because the relationship with the printer need not occupy centre stage any longer.

Both developments make the publisher less tied to the printing press, but even more tied to the timely availability of diverse content. In general, one can say that the economies of scale in the publishing business now have to be found in the use of digital content platforms where the extraction of profits takes place by using one's platform for a wide variety of content that creates value for the selected user community. Instead of focusing on supply-side factors, the demand side is central to a publisher's entrepreneurial decisions. Which content has added value for platform users and enhances the attractiveness of the platform as a whole? Which platform functionality is of particular importance to the target audience?

Once the initial investment in the creation of a digital platform has been made, the cost of adding individual content items - books, articles, news, etc. - is often negligible. The restrictions known from the analogue past - in terms of warehouse and bookshelf capacity - no longer apply in the digital environment. It can be worth keeping niche publications in digital stock as long as the information item concerned supplements the information spectrum available on the platform. The usefulness and profitability of a digital information platform is likely to be the higher, the more information is made available for users in a user-friendly, structured way. Hence, content aggregation and the development of an appropriate platform infrastructure become essential.

More concretely, the shift to the platform-based distribution of aggregated database content allows publishers to run a network that is attractive to contributors (authors) and customers alike. Profit can be created if the database, on the one hand, attracts content providers because the database already has a large number of customers and, on the other hand, attracts customers because of the large number of content providers. Hence, a self-reinforcing process is at work in which a database becomes the more attractive (and the cheaper to run), the bigger it already is. One can speak of a network effect: it becomes attractive to join a network because others have already joined the network. ${ }^{14}$

The platform-based distribution of content can occur in many forms. By integrating journal articles and book contributions in platforms with a particular focus on the information needs of a specific user community, publishers create added value for professionals who obtain the opportunity to improve their performance by using the search functionality and cross-references between diverse information resources that are made available on the platform. At the same time, the platform can serve as a focal point of communication with and among professionals in a given sector. It serves as an information forum where advertisements for products and services are combined with the announcement of news and events and the discussion of regulatory changes and problem solutions.

The creation of platforms also allows publishers to offer room for the active participation of customers in the creation and further development of information. Blogs and content ratings can be useful tools to obtain feedback for the further customization of information offers. In the educational and academic sector, school

\footnotetext{
${ }^{14}$ Farrell and Klemperer (2007, 1974-1976).
} 
and study materials can be offered which go far beyond a fixed educational framework which the publisher develops in accordance with official requirements. Once educational content is offered in digital form, it can take the form of an interactive platform that allows educational institutions to make individual choices by selecting, adding, enriching and restructuring content, recalibrating exercises and involving pupils and students in the further development of platform contents.

Digital content platforms also allow the collection of data about individual use patterns of customers. News and entertainment streams can be aligned with content preferences of readers during the day. Event reviews can follow the respective concert or show through the country to inform potential local audiences about experiences with previous performances.

\subsection{Importance of a Self-Reinforcing Network}

For a profitable digital business model in the publishing sector, it is thus decisive to have a strategy that triggers the self-reinforcing process of a growing network. This will allow the publisher to recoup the investment made in the creation of the platform and the maintenance of the platform infrastructure. A content platform with a strong network effect allows the publisher to make a profit.

As already indicated, the demand side becomes more important in this context. It is indispensable for the growth of the network to attract customers as well as content providers. This means that readers and content providers have an increasingly large bargaining power. The publisher must create a match between the two groups. Hence, it is no longer the successful pre-selection of authors and content, and clever bargaining with printers that guarantees a profit, but the invention of a successful business strategy to arrive at a content platform generating a network effect. ${ }^{15}$

\section{New Business Models and New Assets}

The described disrupting effects of innovation in information and printing technology have a deep impact on the importance of assets in the publishing industry. Some assets that used to be crucial have become largely obsolete, forcing publishers to develop new, sometimes intangible, assets. This is part of a process which Joseph Schumpeter, in 1942, described as "creative destruction". ${ }^{16}$ Instead of the traditional reliance on a particular distribution channel, publishers nowadays seek to build communities around information platforms. The key is to offer the consumer content that adds value as compared to free online information. ${ }^{17}$ In this context, content aggregation, community building, customization and the inclusion of user-generated content can be seen as promising strategies. The task of the publisher may be to offer a $360^{\circ}$ business model, guiding the consumer through all

\footnotetext{
15 Jackson (2017), pp. 49-95.

16 Schumpeter (1942), p. 82.

17 Wernerfelt (1984).
} 
available information that may be of particular interest to the reader community concerned. Moreover, strong brands are likely to remain, also in the digital era.

\subsection{Content Platforms}

Considering the described network effects, a platform can be defined as an integration layer that combines and organizes multiple inputs into a single access point for the user. On a platform, the various inputs interact with each other and create positive feedback loops, thereby creating value for the consumer as well as for the provider. ${ }^{18} \mathrm{~A}$ platform allows a user to access content in a wide range of types and forms, or from various sources and creators. The owner of a platform can offer users value beyond the content itself, in the form of facilitating access to it or organizing information in a particularly useful way. ${ }^{19}$ Given this background, platforms have become very important in various segments of the publishing market as a means of continuing to add value to readers.

A prominent example is the education publishing segment where publishers have transformed from simple content providers into facilitators of the learning process. The traditional approach in the education publishing sector was to implement a learning plan and to sell corresponding books, workbooks and other materials to schools. Nowadays, the task of education publishers has moved from the creation of content to the provision of platforms that serve as a basis for various learning tools and materials. In this context, the pupils' interaction with platform tools creates not only value for the pupils, but also for the publisher who learns about the specific needs of pupils and, accordingly, obtains the opportunity to constantly improve the learning platform. This trend meets the increased demand of schools for customized learning materials which, in turn, follows the transition phase towards education tailored to the individual child. Teachers contribute to content development as well, meaning that, for the publisher, it is the interactive platform infrastructure as a whole - rather than individual content items - that becomes the key asset.

Nevertheless, the quality of the content remains of key importance. In recent years, a significant rise of open education resources and user-generated content initiatives, such as Khan Academy, Listr, Edmodo, Wikiwijsleermiddelenplein and LessonUp, ${ }^{20}$ could be observed. Much of this content is available to schools for free, or at a lower cost than learning materials provided by education publishers. However, a teaching method requires more than just a collection of content that is interactively available. When offering content to schools, education publishers have to consider that the various subjects of teaching must be taught in a logical order. The respective learning process must fit into the available time for the subject to ensure that pre-determined learning goals can be achieved. ${ }^{21}$ In a nutshell, education publishers still have an important task. In particular, the opportunity to add value by providing a concise structure of content and learning materials plays a central role.

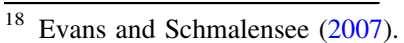

19 Kogut and Zander (1992).

20 Frankwatching and Emiel Ubink (2016).

21 Frankwatching and Emiel Ubink (2016).
} 
However, making the leap from a traditional content provider for schools to a platform provider is not easily achieved. Especially for smaller players, the start-up costs involved in maintaining a platform are a challenge. Technical staff is needed, such as software designers, who have to be integrated into the "corporate culture" of a publisher. Ultimately, an extensive network and a strong brand have become increasingly relevant to education publishers embarking on the creation of learning platforms. As a result, big players already have better chances of being successful, while smaller education publishers may have to focus on a niche market.

A similar development has occurred in the scientific publishing segment, where the shift may have been even more "radical" than in the education sector. The disrupting advancements in information technology created the need for scientific publishers to transform themselves into service providers for scientists and universities, offering knowledge management. Whereas scientific publishers used to be the guardians of the distribution channel of scientific information, the digital age offers academics the opportunity to disseminate their articles themselves via the Internet. As a result, for scientists the bottleneck has become the overload in scientific information, turning the role of the scientific publisher into one of structuring information and reducing the search costs of readers. To accomplish this, many scientific publishers have created platforms for their readers which help them to navigate through the scientific information on offer. One can think of Kluwer's "Navigator" or Springer's "SpringerLink", both including advanced search tools to help users quickly find what they are looking for.

Platforms have become increasingly relevant in the news segment as well. In the Netherlands, for instance, De Persgroep launched its platform "Topics" on which subscribers to one of its newspapers can read articles from other titles of De Persgroep for free. Topics offers all articles from the various newspapers and magazines published by De Persgroep. Using algorithms, the platform will be capable of sorting the articles in accordance with user preferences. Each user will see a different selection of articles based on topics in which the user showed interest before. As a result, Topics constitutes a highly personalized magazine to meet the demand for customization. The main feature of Topics is to sort available information and offer the relevant selection to the consumer. At the same time, an initiative, such as Topics, offers subscribers additional value. In this way, it may enable the publisher to maintain a sufficient number of subscribers. Blendle serves as a further example of platform creation in the news segment.

All these examples illustrate that not only offering the content itself, but also the way in which it is offered is key to a successful business model in today's publishing market. In various publishing segments, publishers now have the role of platform providers with an increasing emphasis on content compilation and management. Hence, platforms - including platform functionality and infrastructure - have become core assets of publishers that offer particular opportunities for the development of new business models.

Platforms are particularly relevant in segments where readers may be confronted with an overload of information or where it is essential that information can be trusted, such as the education and scientific segments. Platforms can also be valuable when readers are interested in content that they cannot find immediately. 
Spotify, for example, generates music suggestions for listeners based on recorded previous music choices. The listener is unlikely to find all this music on his own. One of Spotify's services is thus to help users find the music they want. This concept also seems relevant to the magazine segment where the examples of Blendle and Topics show that readers who are interested in a wide range of topics rather than a specific newspaper brand, may prefer a single access point to select articles of their interest from a wide variety of available information resources. The advantage of such platforms is that they can present the articles in a user-specific and customized manner. For example, Topics will include local information, which means that readers will have the possibility to read local news in addition to the national news offered in the Volkskrant, or additional sport news. ${ }^{22}$

Also in the sector of academic, educational, and professional journals, there seem to be opportunities for the successful establishment of platform services. Kluwer's "Navigator", for instance, provides a single access point for legal professionals to law journal articles, judgments and accompanying case comments. The key to success in the area of platform creation seems to lie in sorting available information and enabling the customer to obtain the information he or she needs quickly and in a comprehensible way. Moreover, one may think of resourceful links between a publisher's platform and other platforms (travel agencies, banking, retail) which guide readers to tailor-made products and services which they may find useful.

Finally, in the segment of book publishing, a joint platform of publishers could be established for the marketing, sale and delivery of e-books. In Germany, for example, three main book retailers - Thalia, Weltbild and Bertelsmann - created such a platform around their common e-reader "Tolino". In this case, the platform takes over the function of a traditional bookshop in which customers can find and obtain literature they are interested in.

\subsection{Communities}

While in the analogue past the distribution channel was a prominent example of an asset that used to be key to publishers' business models, the network or community built around an information platform or individual product, such as a magazine, is an emerging new asset of fundamental importance in the digital environment. Whereas a publisher used to focus on the printed magazine as its product and the readers as its customers, a publisher may nowadays rather focus on the development of a community and network around a magazine, with members that (also) read the magazine.

This network can be utilized to facilitate the exchange of knowledge between community members, and to inform members about the latest developments. In this case, the magazine is no longer solely a product but rather a communication instrument. While subscribers to the magazine may be able to obtain the content of the magazine elsewhere, membership is valuable because it connects the subscriber to relevant other parties and ensures that he or she receives all relevant news about

${ }_{22}$ De Volkskrant and de Rek (2016a). 
the group of which the subscriber is a member. In this context, one could think of industry magazines, but also of magazines addressing a particular interest or hobby.

In other segments of the publishing market, databases with detailed customer information have become an asset. The wide availability of free information on the Internet has forced publishers in the newspaper industry to offer readers more tailored information, customized to their wishes and dependent on the time of the day. Having information on customers' preferences is therefore a key asset that allows the offer of customized services. Newspaper publishers are also involving their readers to a greater extent, offering them the possibility to "like" articles they find interesting or to comment on them. In this way, newspaper publishers are moving towards the creation of digital content platforms for their reader community.

\subsection{Branding}

Building a close relationship with the target group, a publisher not only maintains a network but can also establish a reputation for his brand. In fact, the brand itself can be a publisher's key asset ensuring the maintenance of a group of loyal readers. One could think of lifestyle magazines, opinion magazines and TV guides. Magazines started by and named after a celebrity can serve as examples. However, brand reliance may become increasingly difficult, with younger generations changing their preferences fast and showing less brand loyalty. The advancements in information technology amplify this effect because consumers can read so much online for free that they may be less willing to pay for a subscription to magazines with a particular brand.

Brands are very important in the magazine segment, as they create customer loyalty. A brand adds a specific "flavour" to magazines which is necessary for building a lifestyle-based user community. In the case of lifestyle magazines appearing under the same name around the globe, publishers are in a position to use content on a worldwide scale which, in turn, ensures familiarity with the brand and reduces the costs of production. These economies of scale are not available for purely local brands, for which it can be challenging to recover the costs from a limited group of readers.

A particular challenge, according to the industry, is to introduce younger generations to brands that obtained a strong position in the analogue past. Today's youth no longer identifies itself with certain magazines in the way that previous generations did. A way forward is to use social media, blogs and YouTube channels, aiming to reach young readers by including them and creating attention for the "community" around a magazine's brand. This includes moving from printed content to online content as well as videos. Of course, the challenge is to find payment models around these new business models.

In some cases, the brand is broader than the magazine itself, for example in case of TV scheduling magazines or celebrity magazines. The brand may then be the driving force to sell the magazine - simply as one of the products linked to the brand. At the same time, the brand may be used to offer additional products or services. 
In the newspaper segment, brands constitute a central starting point for the development of new business models as well. The brand gives authority. ${ }^{23}$ Consumers have certain expectations based on the brand. Each newspaper has a certain "flavour", offering a particular view to reality that matches the perception and experiential world of the consumer.

Similarly, particular importance is attached to brands in the scientific publishing segment. A well-established brand gives authority and allows scientific publishers to play a central role in the assessment and validation of content. Given the focus of the academic community on peer-reviewed publications in leading journals and book series of important scientific publishers, the role of brands must not be underestimated.

In the book publishing market, brands are important in a different - and changing - way. Whereas magazines and newspapers are increasingly relying on their brand, in the book segment it is not the publishers, but rather the authors who become the brand. As Jean-Marc van Tol notes, whereas readers were familiar with the names of major publishers in the past, they are now familiar with top authors. ${ }^{24}$ In response, publishers use the names of top authors and expand the range of related "products" beyond the actual book. Top authors also perform at events, write columns, or otherwise develop their "brand" with additional activities. Put differently, a top author can become a key "asset" for a publisher.

\section{Protection Needs}

With regard to the assessment of protection needs arising from the described new business strategies, a remarkable shift comes to the fore: in the analogue past of the printing press, the focus was on protection of the individual information item that formed the centre of investment: an individual book, newspaper or journal article. In the digital future with its content platforms, the focus is different. To the extent that information items are not freely available anyway, publishers may still be interested in the protection of individual works that are made available on a content platform. The crucial point, however, is the protection of the platform as such. A competitor who makes unauthorized use of several books or articles taken from another's platform will still be unable to substitute and erode the market for the platform. By contrast, a competitor who copies decisive features of a content platform - the database infrastructure, functionality and a large part of the collection of information items - constitutes a threat. Hence, the evolution of content platforms as core assets of publishers implies that database protection plays an increasingly important role. Given the reliance on branding and the superstar culture to attract the attention of consumers in the digital environment and achieve loyalty vis-à-vis a particular online platform, trade mark protection and other forms of goodwill protection constitute decisive protection tools as well.

With regard to traditional copyright protection of individual literary and artistic works, however, the situation is less clear. On the one hand, traditional copyright protection remains a decisive factor when it comes to the regulation of the

\footnotetext{
${ }^{23}$ De Volkskrant and Remarque (2016c).

24 De Volkskrant and Putman (2016b).
} 
relationship with individual authors. To ensure sufficient legal certainty about the use of an author's work in the context of new business models, it will be important in many cases to enter into a publication agreement. Copyright law serves as a basis for this contractual relationship. The specific rules of copyright contract law can play a decisive role. ${ }^{25}$ On the other hand, the focus on the protection of individual literary and artistic works does not correspond to the growing importance of content platforms. The importance of copyright protection of individual works is likely to decrease as a result of the transition to platform-based competition. Against this background, it is doubtful whether the proposed new neighbouring right for press publishers would be a step in the right direction.

\subsection{Copyright in Individual Works}

By definition, new business models do not rely on the commercialization of individual works as such. The individual work is only a single voice in the much bigger and much more complex concert of information which the platform offers and organizes. A competitor who copies an individual work will still be unable to offer a meaningful alternative to the original content platform as a whole. Even the taking of several works is unlikely to erode the market for the original platform. Instead, the functionality and structuring of the content platform, and the underlying content database, occupy centre stage. The copying of decisive platform features poses a real threat to new business models.

Therefore, it seems safe to assume that the primary protection needs of publishers developing new business models based on content platforms can be satisfied by offering copyright protection for original compilations of works and other materials. In addition, sui generis database protection enters the picture that affords publishers a robust legal position and considerable legal security for investment in new, platform-based business models. ${ }^{26}$ As to the protection of brands, trade mark law is available which is well developed in the EU. ${ }^{27}$

As to traditional copyright protection, however, the transition to new business models seeking to add value by integrating individual works in complex content platforms has the corollary that copyright protection of individual literary or artistic works becomes less important. ${ }^{28}$ Once businesses focus on the aggregation of content in a way that enhances the usefulness of integrated information for customers, the protection of an individual work - a book, journal article or news

\footnotetext{
25 As to the debate on copyright contract law in The Netherlands and in Germany, see Terhorst (2015), p. 162; Lenselink (2013), pp. 1-11; Wybenga (2011), p. 41; Peeperkorn (2010), p. 167; Poort and Theeuwes (2010), pp. 137-145; Senftleben (2010), p. 146; Cohen Jehoram (2008), p. 303; Lenselink (2005), pp. 453-463; Hugenholtz and Guibault (2004); German Federal Court of Justice, 7 October 2009, cases I ZR 38/07 and I ZR 230/06, available (in German) at http://www.bundesgerichtshof.de; Schack (2001), p. 460; Zirkel (2003), p. 59; Schulze (2005), p. 828; Dietz (2007), p. 465; Dietz (2015), pp. 315-316; Schmitt (2003), pp. 295-296; Schack (2002), p. 853; Reber (2010), p. 708; Peifer (2015), p. 1; Spindler (2012), pp. 921. Article 25c(1) of the Dutch Copyright Act.

26 As to EU sui generis database protection, see Peukert (2016), paras. 80-84; Hugenholtz (2016), pp. 379-420; Derclaye (2013, pp. 340-354); Derclaye (2008).

27 For a detailed analysis of EU trade mark law, see Kur and Senftleben (2017).

${ }^{28}$ For an opposite view emphasizing the growing importance of protecting individual works because of the "unbundling effect" of the digital environment, see Peukert (2016), para. 28.
} 
report - is no longer a primary concern. In the light of the robust layer of database protection under copyright and sui generis standards, copyright in an individual literary and artistic work - which merely constitutes an individual information unit in the convolute of information integrated in a content platform - plays a secondary role.

This secondary role does not imply that copyright in an individual literary or artistic work has become irrelevant altogether. However, it seems obvious that copyright in an individual work (which only forms an individual information item) can hardly serve as an appropriate vehicle to achieve protection of the particular added value following from the creation of a much more complex information infrastructure. With the emergence of new business models focusing on the creation of content platforms, the importance of protecting the underlying database and its particular functionality increases. The importance of protecting individual literary and artistic works, by contrast, decreases.

\subsection{Neighbouring Right for Publishers}

Against this background, it is doubtful whether the grant of an additional neighbouring right would be a step in the right direction. In its communication "Towards a Modern, More European Copyright Framework", the European Commission qualified the possibility for right holders to license and be paid for the use of their content - including content distributed online - as a precondition for a well-functioning marketplace for copyright. According to the Commission,

[t]he production of rich and diverse creative content and innovative online services are part of the same equation. Both - creative content and online services - are important for growth and jobs and the success of the internet economy. $^{29}$

The Commission also referred to growing concern about whether the current EU copyright rules make sure that

the value generated by some of the new forms of online content distribution is fairly shared, especially where right holders cannot set licensing terms and negotiate on a fair basis with potential users. This state of affairs is not compatible with the digital single market's ambition to deliver opportunities for all and to recognise the value of content and of the investment that goes into it. It also means the playing field is not level for different market players engaging in equivalent forms of distribution. ${ }^{30}$

While content production and content-based online services are certainly interconnected, this approach raises the question whether the dichotomy between producers of "rich and diverse creative content" on the one hand, and providers of

\footnotetext{
$\overline{29}$ European Commission (2015), p. 9.

${ }^{30}$ European Commission (2015), p. 9.
} 
"innovative online services" on the other, appropriately reflects current reform priorities in the publishing sector. Publishers increasingly provide innovative online platforms themselves. In the light of the described economic potential of network effects coming along with platform creation, it also seems clear that this development is a step in the right direction: whereas it may be more and more difficult to derive profit from the sale of individual works in the digital environment, online content platforms with added value for users are regarded as a promising basis for generating income in the sector.

Hence, it is doubtful whether initiatives to amend the European copyright framework should focus on the redistribution of revenue accruing from innovative online services instead of encouraging publishers to develop these innovative online services themselves. As publishers can be expected to have in-depth knowledge of the specific information needs of different reader communities and long-standing relationships with authors who can satisfy these information needs, the publishing sector seems ideally placed to establish content platforms with added value itself content platforms that go beyond existing online services and offer new and innovative features.

Instead of emphasizing this remarkable potential of the publishing sector to ensure innovation in the area of tailor-made online services, the reform plans of the European Commission focus on an exclusive right concerning the commercialization of individual literary and artistic works as such. Article 11(1) of the Commission Proposal for a Directive on Copyright in the Digital Single Market ${ }^{31}$ seeks to offer publishers of press publications an exclusive right of reproduction and an exclusive right of making works available in the online environment. These new neighbouring rights would be awarded for a period of 20 years after publication. They would complement the exclusive rights of individual authors following from Arts. 2 and 3(2) of the Information Society Directive. ${ }^{32}$

Given this parallel between the rights of individual authors and the proposed new rights of press publishers, the question arises, which added value the grant of additional exclusive rights has. In most cases, press publishers will receive the rights of reproduction and making available from individual authors as a result of an employment contract (in EU Member States providing for copyright ownership in this case), ${ }^{33}$ a transfer of copyright or an exclusive license. In comparison with these mechanisms for obtaining rights of reproduction and making available, the proposed grant of an additional layer of neighbouring rights seems to offer no substantial benefits. By contrast, the grant of neighbouring rights for publishers that, in substance, are identical with the copyright of authors, may lead to discussions about the necessity of a transfer or license. As press publishers would have their own rights in accordance with the proposal made by the Commission, individual authors contributing to a press publication may feel that there is no longer a need and

\footnotetext{
31 European Commission, 14 September 2016, Proposal for a Directive of the European Parliament and of the Council on Copyright in the Digital Single Market, Doc. COM(2016) 593 final, Art. 11(1).

32 Directive 2001/29/EC of the European Parliament and of the Council of 22 May 2001 on the harmonisation of certain aspects of copyright and related rights in the information society, Official Journal L 167, 22 June 2001, p. 10.

33 For example, see Art. 7 of the Dutch Copyright Act (Auteurswet). Cf. Seignette (2012), pp. 115-140.
} 
justification for a transfer or license, ${ }^{34}$ and that the value of their own copyright is reduced because of the additional right of publishers. ${ }^{35}$

Considering the platform-based business models discussed above, it can be added that the strategy of creating more and more layers of copyright and neighbouring rights relating to individual works appears outdated. It seems to focus attention on a strategy for generating income in the digital environment that is more difficult and less promising than content platform creation. Following the traditional model of commercializing individual works, the approach taken by the Commission distracts from the need to abandon the traditional focus on the publication of individual works and turn to the creation of content platforms to realize network effects. In its public consultation "On the Role of Publishers in the Copyright Value Chain and on the 'Panorama Exception'”, the European Commission asked

whether publishers of newspapers, magazines, books and scientific journals are facing problems in the digital environment as a result of the current copyright legal framework with regard notably to their ability to licence and be paid for online uses of their content ... In particular the Commission wants to consult all stakeholders as regards the impact that a possible change in EU law to grant publishers a new neighbouring right would have on them, on the whole publishing value chain, on consumers/citizens and creative industries. ${ }^{36}$

However, experiments with a neighbouring right or remuneration scheme for news publishers in Germany ${ }^{37}$ and Spain $^{38}$ have already shown that attempts to impose a payment obligation for the use of content fragments on search engines and providers of comparable aggregation services ${ }^{39}$ are unlikely to generate a meaningful new revenue stream for publishers.

The reason for this lies in the interdependence of online content offers and online search and aggregation services. While search engines and comparable content aggregators have an interest in providing the most comprehensive overview of available online content, publishers offering content on the Internet have an interest in search results that enhance the visibility of their content repertoire. As a result of this interdependence, the remuneration claim is also interchangeable: publishers may argue that they should be entitled to compensation for the use of content fragments which search engines use to generate search results; search engines may argue that they should be remunerated for drawing the attention of Internet users to content offered by publishers. ${ }^{40}$

\footnotetext{
34 Cf. the critical comments by Visser (2016), pp. 272-273.

35 Cf. the critical comments by Kretschmer et al. (2016), pp. 592-593; Geiger et al. (Geiger et al. 2016), pp. 11-12; Peukert (2016), para. 128; Xalabarder (2016), pp. 14-15. As to the broader problem of reduced social legitimacy of copyright, see Geiger (2010), pp. 12-14.

36 European Commission (2016), p. 6.

$37 \S 87 f(1)$ of the German Copyright Act (Urheberrechtsgesetz).

38 Article 32(2) of the Spanish Intellectual Property Law (Ley de Propiedad Intelectual).

39 In this sense $\$ 87 \mathrm{~g}(4)$ of the German Copyright Act. For a discussion of the scope of the prohibition of use by search engines and comparable content aggregators, see Hossenfelder (2013), pp. 376-379.

40 Stieper (2013), p. 12. Cf. also Peukert (2016), paras. 33 and 45-46, speaking of a "symbiotic" relationship and stating rightly that a new neighbouring right "cannot generate consumer demand for journalistic content if that demand does not exist."
} 
Given the potential interest of publishers in the indexation of their content offers and the display of adequate search results, the making available of articles on the Internet without access restrictions may also be seen as an indication of implied consent that excludes the invocation of the neighbouring right from the outset. ${ }^{41}$ In the light of the interdependence of interests and claims on both sides, ${ }^{42}$ it is moreover conceivable that search engines and other content aggregators discontinue the use of content fragments instead of paying a licence fee or equitable remuneration.

In Spain, Google closed its Spanish branch of the Google News service and several smaller news aggregators stopped their activities after the introduction of a compulsory remuneration scheme for content fragments on 1 January $2015 .{ }^{43}$ A study conducted by NERA Economic Consulting on behalf of the Spanish Association of Publishers of Periodical Publications showed that during the three months following the entering into force of the new Spanish remuneration right, the number of newspaper website visits, on average, decreased by $6.1 \%$. $^{44}$ The study also showed differences in the impact on news publishers: while big publishers were confronted with a decrease of 5.8\%, publishers of average size were exposed to a $7.1 \%$ reduction of Internet traffic to their websites, and smaller publishers had to cope with a decline amounting to $13.5 \% .^{45}$ Instead of additional revenue, the new Spanish remuneration right thus caused a loss of the market expansion effect of search results indicating newspaper contents. ${ }^{46}$ Given the strong corrosive effect on small publishers, the risk of market concentration and a loss of news diversity must also be taken into account. Experiences with a neighbouring right thus show that, instead of supporting a free and pluralist press, as intended by the European Commission, ${ }^{47}$ the introduction of a neighbouring right may thwart this objective and lead to less news diversity. ${ }^{48}$

In Germany, the neighbouring right of news publishers has been implemented as an exclusive right to prohibit the use of content fragments by search engines and comparable content aggregators. ${ }^{49}$ As a result, the impact of the neighbouring right only comes to the fore in situations where a publisher decides to actively assert the right against search engines. According to a study tabled by the Bundesverband Informationswirtschaft, Telekommunikation und neue Medien e.V. (Bitkom), an enforcement attempt made by the German collecting society VG Media on behalf of several publishers had a corrosive effect on traffic to the websites of the publishers

\footnotetext{
${ }^{41}$ In this sense German Federal Court of Justice, 29 April 2010, case I ZR 69/08, pp. 11-12, available online in German at http://www.bundesgerichtshof.de, published in GRUR 2010, p. 628. Cf. Stieper (2013), p. 16; Peifer (2013), p. 152; Senftleben (2013), pp. 59-67.

42 For a concise overview, see Ensthaler and Blanz (2012), pp. 1107-1109.

43 Xalabarder (2016), pp. 18-21; Geiger et al. (2016), p. 15.

44 NERA Economic Consulting (2015), p. 55.

45 NERA Economic Consulting (2015), p. 55.

46 NERA Economic Consulting (2015), p, iii.

47 European Commission, 14 September 2016, Proposal for a Directive of the European Parliament and of the Council on Copyright in the Digital Single Market, Doc. COM(2016) 593 final, Recital 31.

48 Peukert (2016), paras. 98-101 and 186-188; Geiger et al. (2016), p. 17.

49 Kretschmer et al. (2016), pp. 594-595; Hilty et al. (2016), pp. 4-5; Peukert (2016), para. 105; Xalabarder (2016), pp. 16-17.
} 
involved. Bitkom reports that, reacting to VG Media's claim for license payments, search engines, including Google, decided to no longer display snippets for related publishers' products or to hide the respective search results entirely. Small providers of search services decided to limit or shut down their service. ${ }^{50}$

In the debate on a neighbouring right for publishers, it has also been pointed out that a broad concept of search engines and comparable content aggregation services liable to pay remuneration may include content platforms that are developed by publishers themselves. ${ }^{51}$ This comment is important in the context of new business models in the publishing sector. Considering the transition to platform creation as a central element of new business models, it cannot be ruled out that publishers with new business models based on content databases may have an interest in including snippets and references to information resources that are available elsewhere. Viewed from this perspective, the proposed new neighbouring right of press publishers is problematic. If it is intended to cover the use of content fragments by search engines and content aggregators, it poses an additional hurdle for publishers seeking to create new content platforms with advanced search functions themselves.

\section{Missing Incentive for Platform Creation}

In the light of the difficulty of using copyright in individual literary and artistic works as an effective enforcement tool in the digital environment, and the corrosive effect of attempts to impose a payment obligation on search engines and comparable content aggregators in Germany and Spain, it is doubtful whether initiatives to enhance the copyright protection of individual literary and artistic works in the digital environment are capable of supporting the adaptation of business models in the publishing sector to the digital environment. ${ }^{52}$

In this regard, the publishing sector seems at the crossroads. If new business models are brought into focus, it seems clear that for the necessary adaptation to the digital environment, a strategy is needed that paves the way for the indispensable transition to content platform creation and platform-based competition. Following this maxim, initiatives to strengthen the protection of individual literary and artistic works do not seem helpful. Instead of encouraging the transition to the creation of content platforms, the further expansion of copyright protection may support the maintenance of traditional business models and the traditional focus on the commercialization of individual works. Instead of serving as a catalyst that prompts publishers to switch to new business models, the prospect of stronger protection of copyright in individual works may delay or even impede a broad transition to platform creation, community building and the realization of network effects in the publishing sector.

\footnotetext{
50 Bitkom (2015), pp. 6-7. Cf. Kretschmer et al. (2016), pp. 594-595; Hilty et al. (2016), pp. 4-6; Geiger et al. (2016), p. 14-15.

51 Xalabarder (2014), p. 8.

52 See Peukert (2016), paras. 27 and 47, and Van Eechoud (2017), pp. 40-41, as to a potential corrosive effect on e-only publishers.
} 
The introduction of remuneration schemes for the use of content fragments by content aggregators is likely to have similar effects. Even if a system could be devised that would generate extra income for publishers, a neighbouring right of this nature is likely to divert publishers from the necessity to embark on platform creation themselves. ${ }^{53}$ Instead, publishers may leave the creation of content platforms and aggregation services to third parties. As a result, innovation would take place outside the publishing sector.

\section{Missing Impulse for Platform-Based Competition}

An impediment of necessary modernization steps would have repercussions on society as a whole. If it is true that publishers have in-depth knowledge of the specific information needs of different reader communities and unique relationships with authors who can satisfy these information needs, publishers have a key role to play in the development of premium content platforms and premium content aggregation services. Given their particular knowledge, experience and expertise, publishers seem in a position to enrich the existing online infrastructure of information platforms and services with new, innovative offers that enhance the availability of information resources and reduce information search costs on the Internet. This important contribution to the improvement of the online information infrastructure would not only allow publishers to recoup the investment made in the modernization of their sector and the transition to the establishment of content platforms. It would also have value for society as a whole. Adding a layer of premium content platforms and aggregation services to existing online services, publishers could further enhance access to information and the diversity of content in the digital environment.

Against this background, stronger protection of individual literary and artistic works or new neighbouring rights covering content fragments do not seem a protection priority. Instead, it would be advisable to take measures that support the publishing sector in its transition to content platform creation, community building and the realization of network effects. The further expansion of copyright protection of individual works and attempts to create revenue streams by imposing payment obligations on content aggregators are not among the measures that seem capable of encouraging publishers to embark on this modernization of the publishing sector. These measures may even be counterproductive because they are not unlikely to delay or even impede indispensable modernization steps.

Instead, legislation is needed that paves the way for platform-based competition in the publishing sector. To achieve this goal and realize the described benefits for society as a whole, a relaxation of access and reuse barriers is more appropriate than the adoption of a new neighbouring right that establishes an additional barrier to rights clearance. ${ }^{54}$ The more works become available for inclusion and cross-referencing in

\footnotetext{
53 Cf. Peifer (2013), pp. 150-151.

54 For a discussion of rights clearance problems raised by the proposed new legislation, see Van Eechoud (2017), p. 48.
} 
online content platforms, ${ }^{55}$ the larger the extent to which competition in the publishing sector no longer depends on ownership of a particular repertoire of works but on the user-friendliness and efficiency of the way in which these works are arranged and made available for users with specific information needs. With a sufficiently rich and diverse pool of information resources that is available for inclusion and cross-referencing in content platforms, competition in the publishing sector could take place at the level of the individual user experience. The classification and arrangement of literary and artistic works, the ease of operation, the availability of support tools, the efficiency of the search algorithm etc. would become central to market success. A competitive advantage would follow from the offer of a particularly user-friendly system that further enhances the added value for users.

In other words, publishers would compete for the creation of the aforementioned premium content platforms and premium content aggregation services that would improve the information infrastructure for society as a whole. Besides a reduction of the power of control following from copyright and neighbouring rights, ${ }^{56}$ competition law measures against restrictive licensing practices can be taken into account to arrive at this reconfiguration of competition in the publishing sector. ${ }^{57}$

\section{Conclusion}

New business models in the publishing sector broaden the range of a publisher's activities. Instead of focusing on the commercialization of individual publications, new business models require a strategy that uses publications strategically to build a user community around the offer of information. This implies that publishers use a wide variety of communication channels ranging from traditional information events for professionals in a specific sector, to content offers that are regularly updated in accordance with recorded individual tastes and distributed via social media. Publishers with new business models become media entrepreneurs with a broad spectrum of activities that aim at a user community built around a given information product. The publication of a newspaper, magazine, journal or book no longer constitutes an end in itself. It is only the starting point for a much broader offer of related products and services.

In terms of legal protection standards, the transition from traditional business models (with a focus on the commercialization of individual works) to new business models (based on content platforms, community building and network effects) leads to a shift in protection needs. Once an information platform is developed, individual works - news reports, journal articles, books - merely constitute individual information items that are embedded in a much more complex information

\footnotetext{
55 Cf. Peukert (2016), para. 28, who explicitly refers to the "unbundling" effect - in the sense of demand for access to rich and diverse individual information items - that currently disturbs the publishing sector. Cf. also Wieduwilt (2010), p. 561; Ladeur (2012), p. 423.

56 For proposals leading to this result, see Senftleben (2016), p. 131.

57 For proposals concerning the area of competition law, see Senftleben (2017). As to the debate on the relationship between copyright and competition law, see Drexl (2013).
} 
infrastructure. Representing only a small fraction of the content offered on the platform, the protection of an individual work becomes less important. Instead, the protection of decisive features of the platform as a whole occupy centre stage, in particular protection of the underlying content database containing the entirety of information resources, the search algorithm and other tools that enhance user friendliness.

Hence, copyright and sui generis database protection for compilations of works and other materials are central to new, platform-based business models in the publishing sector. Traditional copyright in individual literary and artistic works, by contrast, plays a secondary role. The present analysis, thus, does not point in the direction of the introduction of stronger copyright protection or the adoption of a new neighbouring right. The further expansion of the protection of individual works is not among the measures that seem capable of encouraging publishers to embark on the transition to platform creation and community building. Instead, the introduction of a neighbouring right covering the use of content fragments may even be counterproductive because this measure is likely to delay or impede indispensable modernization steps. The proposed new legislation is unlikely to support a free and pluralist press. Instead, it may prevent a reconfiguration of competition in the publishing sector that could reduce information search costs and improve the information infrastructure for society as a whole.

Open Access This article is distributed under the terms of the Creative Commons Attribution 4.0 International License (http://creativecommons.org/licenses/by/4.0/), which permits unrestricted use, distribution, and reproduction in any medium, provided you give appropriate credit to the original author(s) and the source, provide a link to the Creative Commons license, and indicate if changes were made.

\section{References}

Barney J (1986) Strategic factor markets: expectations, luck, and business strategy. Manage Sci 32(10):1231-1241

Bundesverband Informationswirtschaft, Telekommunikation und neue Medien e.V. (Bitkom). Ancillary copyright for publishers - taking stock in Germany. Bitkom 2015, Berlin. https://www.bitkom.org/ Bitkom/Publikationen/Ancillary-Copyright-for-Publishers-Taking-Stock-in-Germany.html

Christensen CM (1997) The innovator's dilemma. Harvard Business School Press, Boston, p xv

Christensen CM, Bower JL (1995) Disruptive technologies: catching the wave. Harv Bus Rev 73(1):43-53

Cohen Jehoram H (2008) Komend auteurscontractenrecht. Intellectuele eigendom en reclamerecht 2008:303

Danneels E (2006) Dialogue on the effects of disruptive technology on firms and industries. J Prod Innov Manag 23(1):2-4

De Volkskrant, de Rek W (2016a) Ik ga nooit meer naar een uitgever. http://www.volkskrant.nl/boeken/ik-ga-nooit-meer-naar-een-uitgever a4243695/

De Volkskrant, Putman S (2016b) Abonnees Persgroepkranten krijgen toegang tot alle titels. http://www. volkskrant.nl/economie/abonnees-persgroepkranten-krijgen-toegang-tot-alle-titels a4235408/

De Volkskrant, Remarque P (2016c) De krant blijft altijd bestaan.http://www.volkskrant.nl/media/dekrant-blijft-altijd-bestaan a4242143/

Derclaye E (2008) The legal protection of databases - a comparative analysis. Edward Elgar, Cheltenham

Derclaye E (2013) Database rights: success or failure? The chequered yet exciting journey of database protection in Europe. In: Geiger C (ed) Constructing European intellectual property: achievements and new perspectives. Edward Elgar, Cheltenham, pp 340-354 
Dietz A (2007) Das Urhebervertragsrecht in Deutschland. In: Hilty RM, Geiger C (eds) Impulse für eine europäische Harmonisierung des Urheberrechts. Springer, Berlin, p 465

Dietz A (2015) Schutz der Kreativen (der Urheber und ausübenden Künstler) durch das Urheberrecht oder Die fünf Säulen des modernen kontinentaleuropäischen Urheberrechts. GRUR Int 2015:309-316

Drexl J (2013) Copyright, competition and development, report by the Max Planck Institute for Intellectual Property and Competition Law, Munich, December 2013. http://www.wipo.int/ipcompetition/en/

Ensthaler J, Blanz H (2012) Leistungsschutzrecht für Presseverleger-Notwendiger Schutz von Presseverlagen im Internet oder systemwidriger Eingriff in die Informationsfreiheit? GRUR 2012:1104-1110

European Commission (2015) Communication From the Commission to the European Parliament, the Council, the European Economic and Social Committee and the Committee of the Regions 'Towards a Modern, More European Copyright Framework'. Document COM(2015) 626 final, dated 9 December 2015

European Commission (2016) Public consultation on the role of publishers in the copyright value chain and on the 'panorama exception'. https://ec.europa.eu/digital-single-market/en/news/commissionseeks-views-neighbouring-rights-and-panorama-exception-eu-copyright. Accessed 23 Mar 2016

Evans DS, Schmalensee R (2007) The industrial organization of markets with two-sided platforms. Compet Policy Int 3(1):151-179

Farrell J, Klemperer P (2007) Coordination and lock-in: competition with switching costs and network effects. In: Armstrong M, Porter RH (eds) Handbook of industrial organization (1974-1976), vol 3. North Holland, Amsterdam, pp 1967-2072

Frankwatching, Emiel Ubink (2016) Gaat open content onze lesmethodes vervangen? http://www. frankwatching.com/archive/2016/01/04/gaat-open-content-onze-lesmethodes-vervangen/

Gallagher K (2014) Print-on-demand: new models and value creation. Publ Res Q 30(2):244-248

Geiger C (2010) The future of copyright in europe: striking a fair balance between protection and access to information. Intellect Prop Q 14(1):1-14

Geiger C, Bulayenko O, Frosio G (2016) Opinion of the CEIPI on the European Commission's copyright reform proposal, with a focus on the introduction of neighbouring rights for press publishers in EU law. Centre for International Intellectual Property Studies, Strasbourg

Govindarajan V, Kopalle PK (2006) The usefulness of measuring disruptiveness of innovations ex post in making ex ante predictions. J Prod Innov Manag 23(1):12-18

Hilty RM, Köklü K, Moscon V (2016) Position statement of the Max Planck Institute for Innovation and Competition on the "Public consultation on the role of publishers in the copyright value chain". Max Planck Institute for Innovation and Competition, Munich. http://www.ip.mpg.de/fileadmin/ ipmpg/content/aktuelles/MPI_Position_statement_15_6_2016_def.pdf

Hossenfelder M (2013) Die Nachrichtendarstellung in Suchmaschinen nach der Einführung des Leistungsschutzrechts für Presseverleger. Zeitschrift für Urheber- und Medienrecht 2013:374-379

Hugenholtz PB (2016) Database Directive. In: Dreier T, Hugenholtz PB (eds) Concise European Copyright Law. Kluwer Law International, Alphen aan den Rijn, pp 379-420

Hugenholtz PB, Guibault L (2004) Auteurscontractenrecht: naar een wettelijke regeling?. Institute for Information Law, Amsterdam

Jackson MO, Rogers BW, Zenou Y (2017) The economic consequences of social network structure. J Econ Lit 55(1):49-95

Joskow P (2007) Regulation of natural monopoly. In: Polinsky AM, Shavell S (eds) Handbook of law and economics, vol 2. North Holland, Amsterdam, pp 1227-1348

Kogut B, Zander U (1992) Knowledge of the firm, combinative capabilities, and the replication of technology. Organ Sci 3(3):383-397

Kretschmer M, Dusollier S, Geiger C, Hugenholtz PB (2016) The European Commission's public consultation on the role of publishers in the copyright value chain: a response by the European Copyright Society. EIPR 38(10):591-595

Kur A, Senftleben MRF (2017) European trade mark law-a commentary. Oxford University Press, Oxford

Ladeur K (2012) Ein "Leistungsschutzrecht" für Presseverlage und die Rechtsverfassung der Internetkommunikation. Zeitschrift für Medien- und Kommunikationsrecht 43(5):420-427

Lenselink BJ (2005) De verlening van exploitatiebevoegdheden in het auteursrecht. Sdu Uitgevers, Den Haag 
Lenselink BJ (2013) Auteurscontractenrecht 2.0- Het wetsvoorstel inzake het auteurscontractenrecht. Tijdschrift voor auteurs-, media- en informatierecht 2013:1-11

NERA Economic Consulting (2015) Impacto del Nuevo Artículo 32.2 de la Ley de Propiedad Intelectual-Informe para la Asociación Española de Editoriales de Publicaciones Periódicas (AEEPP). http://www.aeepp.com/noticia/2272/actividades/informe-economico-del-impacto-delnuevo-articulo-32.2-de-la-lpi-nera-para-la-aeepp.html

Peeperkorn D (2010) De lange geschiedenis van het auteurscontractenrecht. Tijdschrift voor auteurs-, media- en informatierecht 2010:167

Peifer K-N (2013) Leistungsschutzrecht für Presseverleger - „Zombie im Paragrafen-Dschungel“oder Retter in der Not? GRUR Prax 2013:149-153

Peifer K-N (2015) Urhebervertragsrecht in der Reform: Der „Kölner Entwurf. GRUR Prax 2015:1

Peukert, A. (2016) An EU related right for press publishers concerning digital uses-a legal analysis. Faculty of Law research paper no. 22/2016. Goethe University Frankfurt, Frankfurt

Poort JP, Theeuwes JJM (2010) Prova d'Orchestra-Een economische analyse van het voorontwerp auteurscontractenrecht. Tijdschrift voor auteurs-, media- en informatierecht 2010:137-145

Reber N (2010) Der "Fairnessparagraph, §32a UrhG. GRUR Int 2010:708-709

Schack H (2001) Neuregelung des Urhebervertragsrechts. Zeitschrift für Urheber- und Medienrecht 2001:453-460

Schack H (2002) Urhebervertragsrecht im Meinungsstreit. GRUR 2002:853-857

Schmitt M (2003) §36 UrhG-Gemeinsame Vergütungsregelungen europäisch gesehen. GRUR 2003:294

Schulze G (2005) Vergütungssystem und Schrankenregelungen. GRUR 2005:828

Schumpeter JA (1942) Capitalism, socialism and democracy. Routledge, London

Seignette J (2012) Authorship, copyright ownership and works made on commission and under employment. In: Quaedvlieg AA, Visser DJG, Hugenholtz PB (eds) A century of dutch copyright law. eLex, Amstelveen

Senftleben MRF (2010) Exportschlager deutsches Urhebervertragsrecht? Het voorontwerp auteurscontractenrecht in Duits perspectief. Tijdschrift voor auteurs-, media- en informatierecht 2010:146

Senftleben MRF (2013) Internet search results—a permissible quotation? RIDA 235:3-111

Senftleben MRF (2016) Copyright reform, GS Media and innovation climate in the EU-euphonious chord or dissonant cacophony? Tijdschrift voor auteurs-, media- en informatierecht 2016:130-133

Senftleben MRF (2017) Monolithic copyright, market power and market definition. In: Liu KC, Hilty RM (eds) Remuneration of copyright owners-regulatory challenges of new business models. Springer, Berlin (forthcoming)

Slater SF, Mohr JJ (2006) Successful development and commercialization of technological innovation: insights based on strategy type. J Prod Innov Manag 23(1):26-33

Spindler G (2012) Reformen der Vergütungsregeln im Urhebervertragsrecht. Zeitschrift für Urheber- und Medienrecht 2012:921

Stieper M (2013) Das Leistungsschutzrecht für Presseverleger nach dem Regierungsentwurf zum 7, UrhRÄndG. Zeitschrift für Urheber- und Medienrecht 2013:10-18

Terhorst AGI (2015) Auteurscontractenrecht: er is een wettelijke regeling! Tijdschrift voor auteurs-, media- en informatierecht 2015:162

Van Eechoud MMM (2017) A publisher's intellectual property right-implications for freedom of expression, authors and open content policies. Study conducted on commission from OpenForum Europe. Institute for Information Law, Amsterdam

Visser DJG (2016) Viermaal auteursrecht in de digitale eengemaakte markt. Nederlands tijdschrift voor Europees recht 2016:267-276

Walsh ST, Kirchhoff BA, Newbert S (2002) Differentiating market strategies for disruptive technologies. IEEE Trans Eng Manage 49(4):341-351

Wernerfelt B (1984) A resource-based view of the firm. Strateg Manag J 5(2):171-180

Wieduwilt H (2010) Das neue Leistungsschutzrecht für Presseverlage—eine Einführung. Kommunikation Recht 13(9):555-561

Wybenga E (2011) Ongebonden werk-Is de literaire sector gebaat bij het voorontwerp auteurscontractenrecht? Tijdschrift voor auteurs-, media- en informatierecht 2011:41

Xalabarder R (2014) The remunerated statutory limitation for news aggregation and search engines proposed by the Spanish Government-its compliance with international and EU law. IN3 working paper series. Universitat Oberta de Catalunya, Barcelona. http://ssrn.com/abstract=2504596 
Xalabarder R (2016) Press publisher rights in the new copyright in the digital single market draft directive. CREATe working paper 2016/15. Centre for Copyright and New Business Models in the Creative Economy, Glasgow

Yu D, Hang CC (2010) A reflective review of disruptive innovation theory. Int J Manag Rev 12(4):435-452

Zirkel MP (2003) Das neue Urhebervertragsrecht und der angestellte Urheber. Wettbewerb in Recht und Praxis 2003:59 